\title{
Restriction fragment length polymorphisms as genetic markers in Vicia
}

\author{
M. van de Ven, \\ W. Powell, \\ G. Ramsay and \\ R. Waugh
}

Scottish Crop Research Institute, Invergowrie, Dundee, Scotland DD2 5DA, U.K.

\begin{abstract}
Genetic variability at the nucleic acid level has been examined in 16 Vicia faba accessions and in four Vicia species. Both six and four base-pair cutting restriction enzymes together with cDNA clones were used to assess the level of polymorphism detectable in Vicia section Faba. Nei's estimate of the number of shared fragments and principal co-ordinate analysis were used to examine and quantify the relationship between the Vicia accessions. The degree of polymorphism detected was considerably reduced when the four wild Vicia species were excluded from the analysis. One Vicia faba genotype, $\mathrm{A} \times \mathrm{B} \times \mathrm{C}$, a three-way hybrid, was responsible for the majority of the RFLPs identified within the Vicia faba genotypes. The identification of hybridisable but diverse parents will improve the efficiency of creating a linkage map based on molecular markers. The nature of the polymorphism detected in Vicia is discussed together with the role of molecular markers in Vicia faba improvement programmes.
\end{abstract}

\section{INTRODUCTION}

Vicia faba L. ranks as the most important grain legume in western Europe on the basis of annual tonnage produced and fifth ranked on world basis (Hebblethwaite et al., 1984). Despite its economic importance our knowledge of the basic genetics of this protein-rich diploid $(2 n=2 x=12)$ organism is lacking. Ward and Chapman (1986) reported that only 27 nuclear loci had been identified in $V$. faba. These genetic loci consist primarily of morphological traits and their specific chromosomal location is largely unknown. Due to the pleiotropic effects associated with morphological mutant loci many of these markers are undesirable in a Vicia faba breeding programme. These factors together with the recessive nature of the mutant alleles have severly hindered the development and exploitation of genetic markers in this crop. Based on available morphological markers the construction of a genetic map of Vicia faba using conventional technology would be a slow process.

In order to expedite the production of linkage maps isozymes have been used in a range of crop plants (Tanksley and Orton, 1983). These biochemical markers are generally selectively neutral, well distributed over the genome and interact in a co-dominant manner. Protein or isozyme variants have been used in Vicia for evolutionary and taxonomic studies (Yamamoto, 1986; Kaser and Steiner, 1983), inbred line recognition and the determination of outcrossing frequencies (Gates and Boulter, 1979, 1980) and cultivar identification (Bassiri and Roumani, 1977). However, only a limited number of isozymes have been subjected to a rigorous genetical analysis (Peat and Adham, 1984, Mancini et al., 1989). While it is anticipated that isozyme markers will contribute significantly to our understanding of Vicia genetics their relatively limited numbers will limit their usefulness in constructing a linkage map.

Molecular markers share a number of advantages with isozymes and have the potential to generate a large number of markers for use in genetical analyses (Michelmore and Hulbert, 1987). Linkage maps based on Restriction Fragment Length Polymorphisms (RFLPs) are being developed in several crops: tomato (Bernatzky and Tanskley, 1986), maize (Helentjaris et al., 1986; Burr et al., 1988), lettuce (Landry et al., 1987) and potato (Bonierbale et al., 1988; Gebhardt et al., 1989). The potential usefulness of RFLPs is dependent on the degree of polymorphism existing among the organisms of interest. This feature of molecular markers is most evident when we consider the creation of a linkage map in tomato (Tanksley et al., 1989). Both the 
creation and exploitation of linkage maps in tomato have involved interspecific hybridisation between Lycopersicon esculentum and L. chmielewskii (Nienhuis et al., 1987; Paterson et al., 1988). Identifying the most genetically diverse parents for the creation of a segregating population is therefore a key feature for the development of a linkage map. Since interspecific hybrids invoving $V$. faba cannot be produced (Ramsay and Pickersgill, 1986) the identification of sexually hybridisable but diverse parents is obviously important. As a first step in the creation of a linkage map in Vicia faba we have assessed the level of polymorphism for molecular markers in Vicia genotypes. Parents exhibiting a high degree of polymorphism have been identified for the creation of a segregating mapping population.

\section{MATERIALS AND METHODS}

\section{Plant material}

Sixteen accessions of Vicia faba and four other species from Vicia section Faba were selected from the collection present at the Scottish Crop Research Institute. Accessions were chosen to represent the full spectrum of variation within $V$. $f a b a$ and to include modern cultivars and related species. A list of the accessions of $V$. faba and other species is given in table 1.
For the wild species part of the seedcoat was removed to promote germination. Ten plants of each accession were grown in a greenhouse in $7 \mathrm{~cm}$ square pots filled with John Innes compost No. 2 . After 3-10 weeks young leaves of each individual plant were harvested, freeze dried, ground in liquid nitrogen and stored at $-20^{\circ} \mathrm{C}$.

\section{DNA isolation}

Total genomic DNA was isolated by a modification of the procedure of Saghai-Maroof et al. (1984). Powdered freeze dried material was mixed with CTAB extraction buffer ( $100 \mathrm{mM}$ TRIS $p \mathrm{H} \mathrm{7 \cdot 5,1}$ per cent CTAB, $0.7 \mathrm{M} \mathrm{NaCl}, 10 \mathrm{mM}$ EDTA, 1 per cent 2-mercaptoethanol) and incubated for one hour at $60^{\circ} \mathrm{C} .9 \mathrm{ml}$ of extraction buffer was used per $300-500 \mathrm{mg}$ of tissue. The mixture was extracted with chloroform: isoamyl alcohol $(24: 1)$ and centrifuged at $3500 \mathrm{rpm}$ for $20 \mathrm{~min}$. The DNA containing aqueous phase was further purified with phenol and chloroform:IAA extractions prior to precipitation by addition of $0.6 \mathrm{vol}$ of isopropanol. The precipitates were washed in 70 per cent ethanol and dissolved in an excess of TE buffer $(10 \mathrm{mM}$ TRIS- $\mathrm{HCl}, 1 \mathrm{mM}$ EDTA, $p \mathrm{H} \mathrm{8.0)}$. Finally, the DNA preparations were treated with RNase A $(10 \mu \mathrm{g} / \mathrm{ml})$ for $15 \mathrm{mins}$ at $68^{\circ} \mathrm{C}$, reprecipitated with ethanol and dissolved in a small volume of TE at approximately $0.5 \mathrm{mg} / \mathrm{ml}$. The DNA concentration was estimated by band-intensity on ethidium bromide stained gels.

Table 1 Plant material

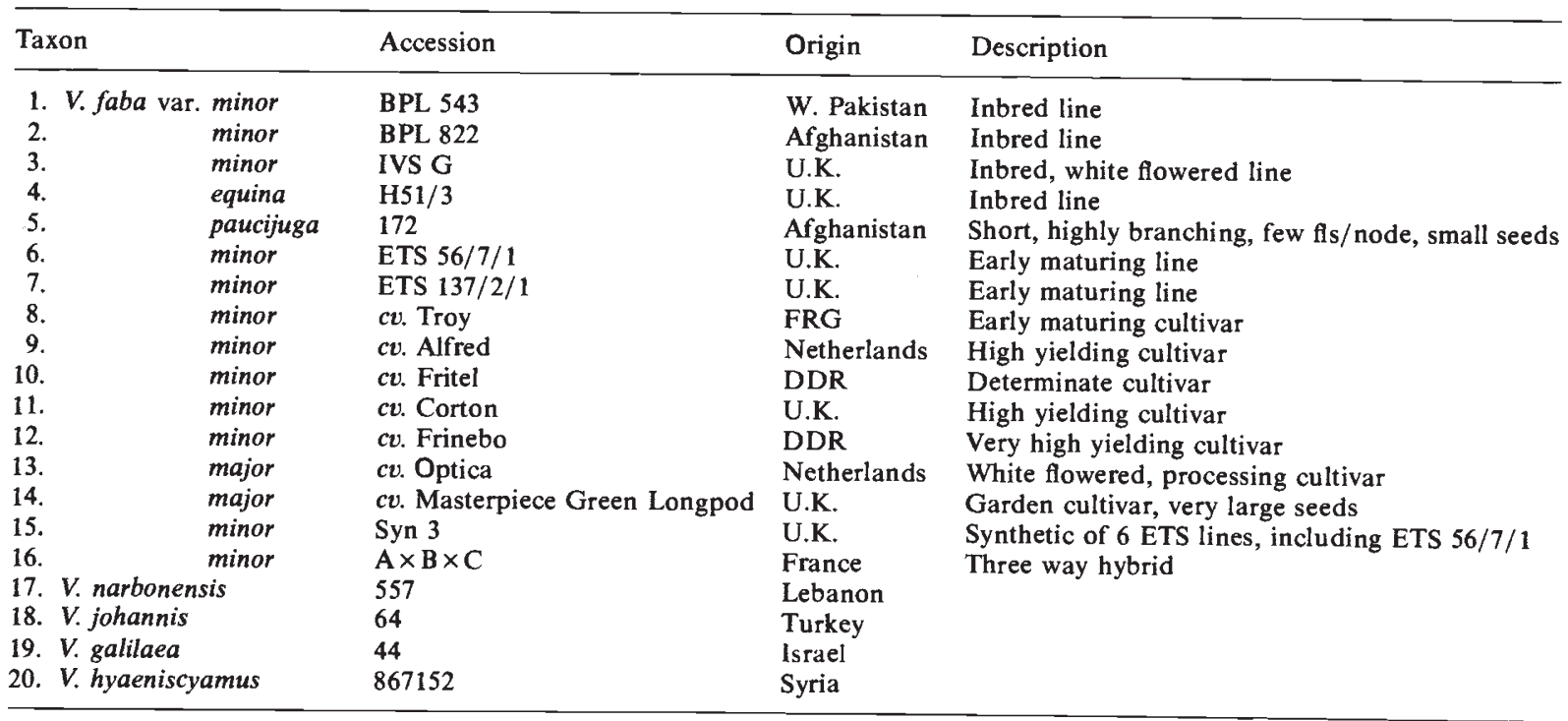


Restriction digests, electrophoresis and southern transfer

DNA from three plants of each line was combined and digested with the following restriction enzymes: BamHI, Eco RI, Eco RV and Hind III, which recognise 6-base pair sequences. Digestion was carried out in a total volume of $100 \mu \mathrm{l}$ using $10 \mu \mathrm{g}$ of DNA, 50 units of enzyme, and $1 \times$ standard digestion buffer $(0.033 \mathrm{M}$ TRIS-Acetate, $p \mathrm{H} 7 \cdot 8,0.065 \mathrm{M}$ potassium acetate, $10 \mathrm{mM}$ magnesium acetate, $4 \mathrm{mM}$ spermidine, $0.5 \mathrm{mM}$ dithiothreitol) overnight. Digested DNA was precipitated by addition of $0 \cdot 1$ vol. $3 \mathrm{M}$ Na Acetate and 2 vol. 100 per cent EtOH, washed in 70 per cent $\mathrm{EtOH}$, dried and re-dissolved in TE. DNA fragments generated after digestion with 6 bp cutters were separated according to length on 1 per cent agarose gels with $1 \times$ TBE $(0.089 \mathrm{M}$ Tris, $0.089 \mathrm{M}$ boric acid, $0.002 \mathrm{M}$ EDTA) as running buffer. DNA was transferred to nylon membranes (either Zeta-probe (BIO-RAD) or Hybond $\mathrm{N}^{+}$ (Amersham)) using the alkaline blotting procedure of Reed and Mann (1985). Alternatively, AluI, HaeIII, HpaI, MboI, MspI, PalI, RsaI or TaqI digested DNA was prepared and electrophoresed on $40 \mathrm{~cm}$ denaturing polyacrylamide gels as described by Gebhardt et al. (1989). DNA was transferred to the membrane electrophoretically in $0.4 \times$ TBE for 1 hour at $1 \mathrm{~mA}$ constant current in a Biorad electroblotting tank surrounded by iced water. DNA was bound to the membranes by baking at $80^{\circ} \mathrm{C}$ for 2 hours.

\section{Library construction}

RNA was isolated according to the method of Logemann et al. (1987) using $10 \mathrm{~g}$ of fresh leaves of Vicia faba $c v$. Optica. Double stranded cDNA was synthesised using a cDNA-synthesis-kit (Pharmacia) following the manufacturers instructions. The cDNA was ligated to EcoRI adaptors and cloned into the EcoRI site of pUC13. DH5 $\alpha$ bacterial cells were transformed and recombinants identified as white colonies on ampicillin plates containing X-gal and IPTG (Maniatis et al., 1982). Plasmids were isolated by the rapid alkaline SDS procedure of Silhavy et al. (1984). Clones containing inserts between $0.4 \mathrm{~kb}$ and $2.0 \mathrm{~kb}$ were used for probes.

\section{Known function probes}

DNA probes of known function and their sources are given in table 2 .

\section{Probe preparation}

To separate inserts from vector, plasmid DNAs were digested with EcoRI and run on 5 per cent polyacrylamide gels (Maniatis et al., 1982). Inserts were excised and isolated using a UEA electroelution apparatus (Undirectional Electroelutor Analytical, IBI) cleaned with phenol and chloroform:IAA extractions, precipitated with ethanol and dissolved in a small vol of TE. To estimate the concentration of the probe a small portion was run on an agarose gel alongside standards.

The probes were labelled with alpha $\left[{ }^{32} \mathrm{P}\right] \mathrm{dCTP}$ (specific activity $3000 \mathrm{Ci} / \mathrm{mmol}$ (Amersham)) using the random primer labelling method of Feinberg and Vogelstein (1984).

\section{Hybridisation and authoradiography}

The prehybridisation buffer contained: $5 \times \mathrm{SSPE}$, 0.5 per cent SDS, $5 \times$ Denhardts solution, $100 \mu \mathrm{g} / \mathrm{ml}$ sonicated salmon sperm DNA. The hybridisation buffer contained the same with the addition of Dextransulfate to 10 per cent $(\mathrm{w} / \mathrm{v})$. Membranes were pre-washed in $2 \times \mathrm{SSC}$ and prehybridised in glass bottles for one hour to overnight at $65^{\circ} \mathrm{C}$ in a rotating oven (Hybaid). Labelled probe was denaturated by heating to $100^{\circ} \mathrm{C}$ for $5 \mathrm{~min}$ and added to approximately $20 \mathrm{ml}$ of hybridisation buffer at $65^{\circ} \mathrm{C}$. Hybridisation was for at least $12 \mathrm{hr}$ at $65^{\circ} \mathrm{C}$. Membranes were washed in $2 \times \mathrm{SSC}, 0.5$ per cent SDS at room temperature for $15 \mathrm{~min}$; $2 \times \mathrm{SSC}, 0 \cdot 1$ per cent SDS at room temperature for

Table 2 Clones of known function

\begin{tabular}{llll}
\hline Probe & Function & Source & Reference \\
\hline pBG 35 & rDNA repeat & Flax & Goldsbrough and Cullis (1981) \\
pRC 221 & Vicillin & Pea & Lycett et al. (1984) \\
pAD 4.4 & Legumin & Pea & Lycett et al. $(1984)$ \\
pCW 27 & Waxy & Maize & Rhode et al. (1987) \\
pBG 13 & 5S RNA repeats & Flax & Goldsbrough et al. $(1981)$ \\
pGI-U2 & Phosphoglucose isomerase & Clarkia & Tait et al. $(1988)$ \\
\hline
\end{tabular}


$15 \mathrm{~min} ; 0 \cdot 1 \times \mathrm{SSC}, 0 \cdot 1$ per cent SDS at room temperature for $15 \mathrm{~min} ; 0 \cdot 1 \times \mathrm{SSC}, 0 \cdot 1$ per cent SDS at $65^{\circ} \mathrm{C}$ for $15 \mathrm{~min}$. The membranes were sealed in plastic bags and autoradiographed at $-70^{\circ} \mathrm{C}$ for one to 7 days using Fuji NIF-RX X-ray film with 2 intensifying screens. The membranes were repeatedly stripped and re-probed (up to 10 times). To strip, boiling $0 \cdot 5-0 \cdot 7$ per cent SDS was poured over the blots in a sandwich box and allowed to cool to room temperature. The membranes were autoradiographed overnight to check that the probe was removed.

\section{RESULTS}

Thirty-eight different clones randomly selected from a cDNA library ( $c a .1 .8 \times 10^{6}$ clones, average insert size $800 \mathrm{bp}$ ) constructed in pUC 13 were chosen as potential RFLP probes. These were used to sequentially screen filters to which DNA from the $16 V$. faba accessions and four wild species had been transferred. The Vicia DNA was digested with four restriction enzymes: BamHI, EcoRI, EcoRV and HindIII and examples of the level of polymorphism detected for two probe/enzyme combinations are given in fig. 1 . The patterns detected by the cDNA probes could be divided into three groups. The first two of these were also observed in soybean (Apuya et al., 1988). These were: (1) A simple pattern of hybridising fragments with one to three bands per track (fig. 2(a)); (2) More than three bands but a relatively simple pattern (fig. 2(b)); (3) Complex restriction fragment patterns. The first class accounted for the majority of the probes. The last class often consisted of a few intensely hybridising fragments which shared little variation and more polymorphic minor fragments (e.g., fig. 5b). An explanation for the polymorphisms detected in the minor hybridising fragments has been suggested previously by Gebhardt et al. (1989) who obtained similar results in potato. They proposed that the complex patterns are most likely derived from multiple copy sequences containing homomorphic core fragments but differing in polymorphic borders according to the position of the lst restriction site in the flanking DNA. A similar explanation is consistent with the patterns obtained in $V$. faba.

Of the 38 probes, the hybridisation patterns from 14 were excluded from the results either because no hybridisation signal was detected or the signal was too weak to be useful. Of the remaining 24 probes, in 62 probe enzyme combinations, 20 detected at least one polymorphism. These results are summarised in table 3.

a.
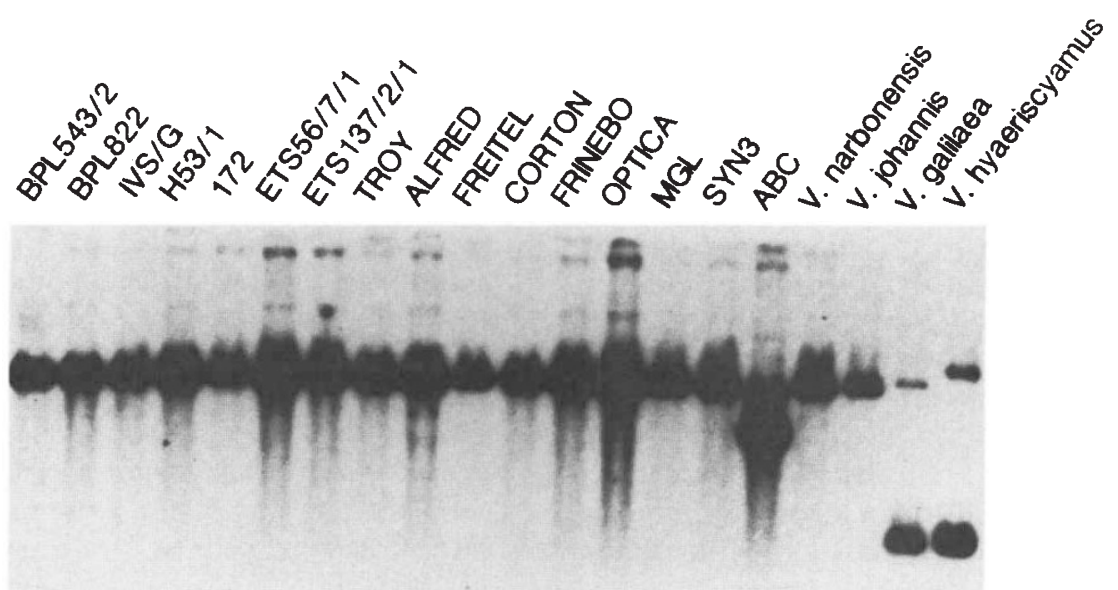

b.

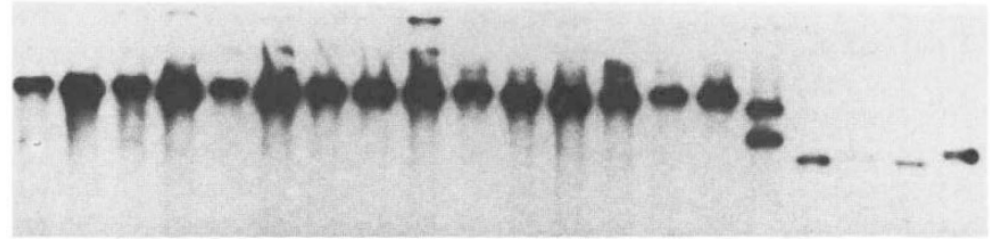

Figure 1 Polymorphism on the 20 Vicia accessions. (a) Restricted with enzyme HindIII and probed with cDNA probe $7 \cdot 14$. (b) Restricted with enzyme EcoRV and probed with cDNA probe 5.6. 


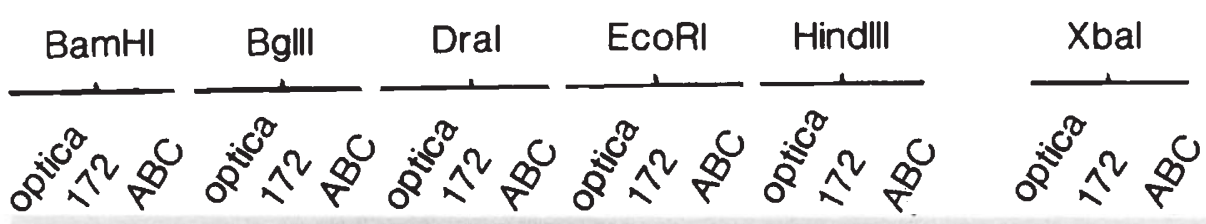

a.

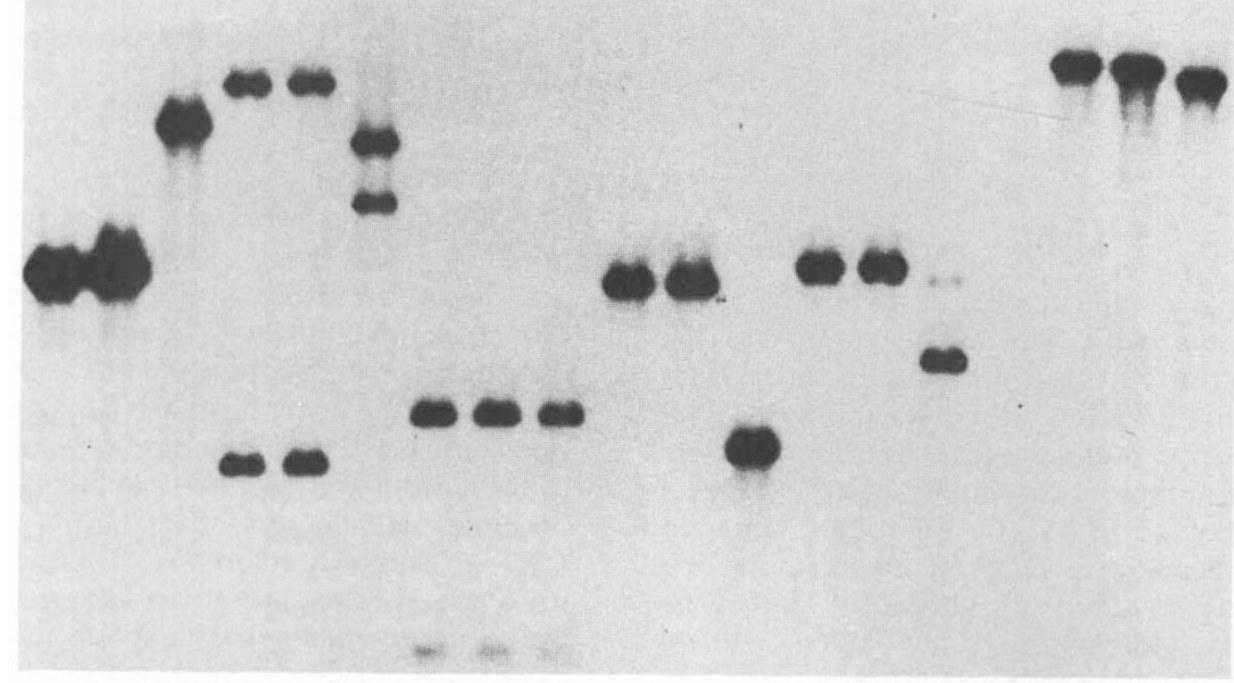

b.

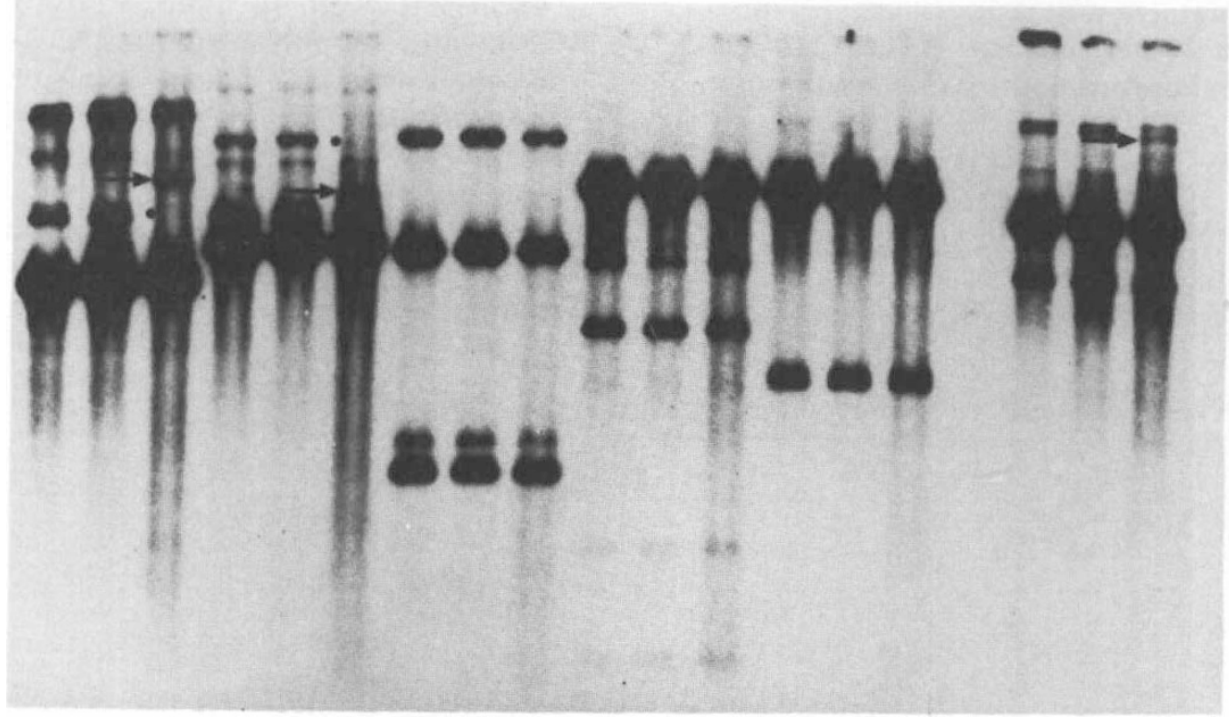

Figure 2 (a) A simple RFLP pattern of Optica, 172 and $A \times B \times C$ probed with cDNA probe $7 \cdot 14$ and restricted with six six-base pair recognising enzymes. (b) Parental screening using cDNA probe $8 \cdot 43$. No polymorphism is detected between the Optica and 172. Polymorphism is shown between 172 and $\mathrm{A} \times \mathrm{B} \times \mathrm{C}$ with the restriction enzymes: Bam HI, BglII and $X b a I$. Arrows and dots indicate polymorphic bands.

The percentage of probes detecting polymorphism between all the Vicia genotypes examined varied from 75 per cent with EcoRV to 56.3 per cent with HindIII. However the proportion of polymorphic probes identified is reduced when the calculation is based on the $16 \mathrm{~V}$. faba accessions. There are significant differences $\left(\chi_{(3)}^{2}=\right.$
$14 \cdot 5^{* * *}$ ) between restriction enzymes in terms of the number of probes detecting polymorphism. Most polymorphism is detected with EcoRV (57 per cent) and least with EcoRI (25 per cent).

The nature of the polymorphism detected for the 20 Vicia genotypes is presented in the form of a similarity matrix in table 4 . Nei's estimate of 
Table 3 Percentage probes detecting polymorphism between Vicia genotypes for four restriction enzymes

\begin{tabular}{llll}
\hline Enzyme & $\begin{array}{l}\text { Recognition } \\
\text { sequence }\end{array}$ & $\begin{array}{l}\text { \% Probes polymorphic } \\
\text { between all genotypes }\end{array}$ & $\begin{array}{l}\text { \% Probes polymorphic } \\
\text { within Vicia faba } \\
\text { genotypes }\end{array}$ \\
\hline Eco RI & GAATTC & $60 \cdot 9$ & 25 \\
Eco RV & GATATC & $75 \cdot 0$ & $57 \cdot 1$ \\
Bam $\mathrm{HI}$ & CGATCC & $62 \cdot 5$ & $43 \cdot 8$ \\
HindIII & AAGCTT & $56 \cdot 3$ & 33 \\
& & $\chi_{(3)}^{2}=3 \cdot 0 \mathrm{~ns}$ & $\chi_{(3)}^{2}=14 \cdot 5^{* * *}$ \\
\hline
\end{tabular}

$* * * P>0.01$.

similarity based on the number of shared fragments (Nei and Lei, 1979) was used to generate the matrix. Reference to table 4 highlights the distinction between the Vicia wild species and the V. faba genotypes. Of greater significance is the relatively low level of similarity detected at the DNA level between genotype $16(\mathrm{~A} \times \mathrm{B} \times \mathrm{C})$ and the other 15 Vicia faba genotypes. In order to examine and quantify the relationship between the Vicia accessions in more detail principal co-ordinate analysis was undertaken. Fig. 3 represents the first two principal co-ordinates of the data that accounts for 70 per cent (54 per cent and 16 per cent) of the total variation. With the exception of $\mathrm{A} \times \mathrm{B} \times \mathrm{C}$ the $15 \mathrm{~V}$. faba accessions dominate the bottom right quadrant of the graph. $V$. johannis, $V$. galilaea, and $V$. hyaeniscyamus are associated in the bottom left of the quadrant. Both $V$. narbonensis and $\mathrm{A} \times \mathrm{B} \times \mathrm{C}$ are clearly separated from the other accessions. The salient feature is the identification of $\mathrm{A} \times \mathrm{B} \times \mathrm{C}$ as being quite distinct from the other Vicia faba accessions. The identification of hybridisable but relatively diverse parents for the generation of a segregating population is highly desirable and represents a key aspect of the production of a genetic linkage map based on molecular markers.

The three-way hybrid $\mathrm{A} \times \mathrm{B} \times \mathrm{C}$ is responsible for a large proportion of the variation detected in the Vicia faba gene pool sampled. Information for 24 of the probes tested with four restriction enzymes is given in table 5. Twelve of the 24 detected useful polymorphisms between $\mathrm{A} \times \mathrm{B} \times \mathrm{C}$ and the remaining $V$. faba accessions. There are significant differences between restriction enzymes in the level of polymorphism detected. Of the 13 probes ( 27 probe/enzyme combination) detecting differences between $\mathrm{A} \times \mathrm{B} \times \mathrm{C}$ and the remaining accessions, 8 were detected with only a single restriction enzyme.

Table 4 Nei's estimate of genetic similarity based on the proportion of shared fragments 1-20, refer to the genotypes in Table 1

\begin{tabular}{|c|c|c|c|c|c|c|c|c|c|c|c|c|c|c|c|c|c|c|c|c|}
\hline & 1 & 2 & 3 & 4 & 5 & 6 & 7 & 8 & 9 & 10 & 11 & 12 & 13 & 14 & 15 & 16 & 17 & 18 & 19 & 20 \\
\hline 1 & $1 \cdot 00$ & & & & & & & & & & & & & & & & & & & \\
\hline 2 & $1 \cdot 00$ & $1 \cdot 00$ & & & & & & & & & & & & & & & & & & \\
\hline 3 & 0.95 & 0.95 & 1.00 & & & & & & & & & & & & & & & & & \\
\hline 4 & 1.00 & $1 \cdot 00$ & 0.95 & $1 \cdot 00$ & & & & & & & & & & & & & & & & \\
\hline 5 & 0.95 & 0.95 & 0.90 & 0.95 & $1 \cdot 00$ & & & & & & & & & & & & & & & \\
\hline 6 & $1 \cdot 00$ & $1 \cdot 00$ & 0.95 & $1 \cdot 00$ & 0.95 & $1 \cdot 00$ & & & & & & & & & & & & & & \\
\hline 7 & 1.00 & 1.00 & 0.95 & $1 \cdot 00$ & 0.95 & 1.00 & 1.00 & & & & & & & & & & & & & \\
\hline 8 & $1 \cdot 00$ & $1 \cdot 00$ & 0.95 & $1 \cdot 00$ & 0.95 & 1.00 & 1.00 & 1.00 & & & & & & & & & & & & \\
\hline 9 & $1 \cdot 00$ & $1 \cdot 00$ & 0.95 & 1.00 & 0.95 & 1.00 & $1 \cdot 00$ & 1.00 & $1 \cdot 00$ & & & & & & & & & & & \\
\hline 10 & 1.00 & $1 \cdot 00$ & 0.95 & 1.00 & 0.95 & 1.00 & $1 \cdot 00$ & $1 \cdot 00$ & $1 \cdot 00$ & $1 \cdot 00$ & & & & & & & & & & \\
\hline 11 & 0.97 & 0.97 & 0.92 & 0.97 & 0.92 & 0.97 & 0.97 & 0.97 & 0.97 & 0.97 & 1.00 & & & & & & & & & \\
\hline 12 & $1 \cdot 00$ & $1 \cdot 00$ & 0.95 & $1 \cdot 00$ & 0.95 & 1.00 & $1 \cdot 00$ & 1.00 & 1.00 & $1 \cdot 00$ & 0.97 & $1 \cdot 00$ & & & & & & & & \\
\hline 13 & 0.97 & 0.97 & 0.92 & 0.97 & 0.97 & 0.97 & 0.97 & 0.97 & 0.97 & 0.97 & 0.95 & 0.97 & $1 \cdot 00$ & & & & & & & \\
\hline 14 & 0.97 & 0.97 & 0.92 & 0.97 & 0.97 & 0.97 & 0.97 & 0.97 & 0.97 & 0.97 & 0.95 & 0.97 & 0.95 & 1.00 & & & & & & \\
\hline 15 & $1 \cdot 00$ & $1 \cdot 00$ & 0.95 & $1 \cdot 00$ & 0.95 & $1 \cdot 00$ & $1 \cdot 00$ & 1.00 & $1 \cdot 00$ & 1.00 & 0.97 & 1.00 & 0.97 & 0.97 & 1.00 & & & & & \\
\hline 16 & 0.51 & 0.51 & 0.46 & $0 \cdot 51$ & 0.49 & 0.51 & 0.51 & 0.51 & 0.51 & 0.51 & 0.49 & 0.51 & 0.49 & 0.51 & 0.51 & $1 \cdot 00$ & & & & \\
\hline 17 & 0.32 & 0.32 & 0.32 & 0.32 & 0.32 & $0 \cdot 32$ & 0.32 & $0 \cdot 32$ & $0 \cdot 32$ & 0.32 & 0.29 & 0.32 & 0.32 & 0.32 & 0.32 & $0 \cdot 13$ & $1 \cdot 00$ & & & \\
\hline 18 & $0 \cdot 29$ & $0 \cdot 29$ & 0.34 & $0 \cdot 29$ & 0.26 & 0.29 & 0.29 & 0.29 & 0.29 & 0.29 & 0.26 & 0.29 & 0.26 & 0.29 & 0.29 & 0.13 & 0.38 & 1.00 & & \\
\hline 19 & 0.29 & 0.29 & 0.32 & 0.29 & $0 \cdot 26$ & 0.29 & 0.29 & 0.29 & 0.29 & 0.29 & 0.26 & 0.29 & 0.26 & 0.29 & 0.29 & $0 \cdot 13$ & $0 \cdot 30$ & 0.76 & $1 \cdot 00$ & \\
\hline 20 & 0.29 & 0.29 & $0 \cdot 32$ & 0.29 & $0 \cdot 26$ & 0.29 & 0.29 & 0.29 & 0.29 & 0.29 & 0.26 & 0.29 & 0.26 & 0.29 & 0.29 & $0 \cdot 13$ & 0.27 & 0.73 & 0.89 & 1.00 \\
\hline
\end{tabular}




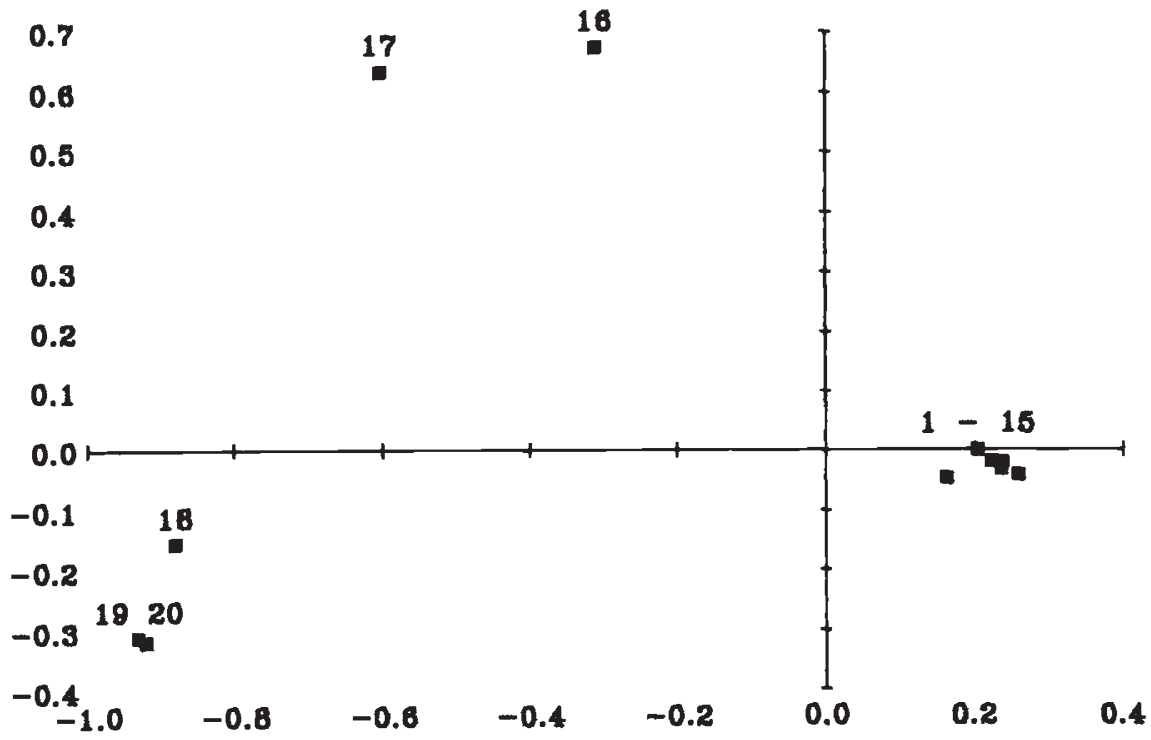

Figure 3 Principal co-ordinate analysis of the RFLP data for the 20 Vicia genotypes examined.

Table 5 Polymorphism attributable to $\mathrm{A} \times \mathrm{B} \times \mathrm{C}$ for $24 \mathrm{cDNA}$ clones and four restriction enzymes

\begin{tabular}{|c|c|c|c|c|c|}
\hline Probe & Eco RI & Eco RV & HindIII & Bam HI & $\begin{array}{l}\text { Polymorphic } \\
\text { enzymes }\end{array}$ \\
\hline 1.5 & - & - & - & - & 0 \\
\hline $2 \cdot 7$ & - & + & - & - & 1 \\
\hline $2 \cdot 9$ & nd & + & + & nd & 2 \\
\hline $2 \cdot 10$ & - & nd & nd & - & 0 \\
\hline $2 \cdot 11$ & - & + & - & - & 1 \\
\hline $4 \cdot 3$ & - & - & - & - & 0 \\
\hline $4 \cdot 7$ & - & - & - & - & 0 \\
\hline $4 \cdot 13$ & - & nd & - & - & 0 \\
\hline 5.6 & + & + & + & + & 4 \\
\hline $5 \cdot 15$ & nd & - & nd & nd & 0 \\
\hline $7 \cdot 4$ & nd & nd & nd & - & 0 \\
\hline $7 \cdot 8$ & - & - & nd & nd & 0 \\
\hline $7 \cdot 14$ & + & nd & + & nd & 2 \\
\hline $7 \cdot 15$ & nd & nd & - & - & 0 \\
\hline $7 \cdot 17$ & - & + & nd & nd & 1 \\
\hline $7 \cdot 18$ & - & - & - & - & 0 \\
\hline $7 \cdot 19$ & + & - & nd & nd & 1 \\
\hline $7 \cdot 28$ & - & + & - & + & 2 \\
\hline $8 \cdot 3$ & nd & nd & + & + & 2 \\
\hline $8 \cdot 5$ & nd & nd & - & + & 1 \\
\hline $8 \cdot 13$ & - & + & nd & - & 1 \\
\hline $8 \cdot 38$ & nd & nd & - & nd & 0 \\
\hline 8.42 & - & nd & & + & 1 \\
\hline 8.43 & nd & nd & - & + & 1 \\
\hline Polymorphic probes & 3 & 7 & 4 & 6 & $\chi_{(3)}^{2}=17 \cdot 6^{* * *}$ \\
\hline Tested & 16 & 14 & 16 & 16 & \\
\hline$\%$ & $18 \cdot 8$ & 50 & 25 & $37 \cdot 5$ & \\
\hline
\end{tabular}

+ , polymorphism; -, non-polymorphic; nd, not determined. **** $P>0.01$. 
In addition to $\mathrm{A} \times \mathrm{B} \times \mathrm{C}, 172$ and Optica were chosen as potential parents for the construction of a linkage map based on RFLPs. Table 6 summarises the results for the parental screening with seven 6 bp cutting restriction enzymes. Table $6(\mathrm{a})$ indicates the polymorphic probe/enzyme combination for $\mathrm{A} \times \mathrm{B} \times \mathrm{C}$ and 172 and table 6(b) for Optica and 172. Twenty-eight anonymous polymorphic probes were identified between $\mathrm{A} \times \mathrm{B} \times \mathrm{C}$ and 172. Clones of known function particularly

Table 6a Probes defining RFLP markers with different enzymes. Polymorphism shown between $\mathrm{A} \times \mathrm{B} \times \mathrm{C}$ and 172

\begin{tabular}{|c|c|c|c|c|c|c|c|c|c|}
\hline Probe & Size $(k b)$ & $B a m \mathrm{HI}$ & $B g I I$ & DraI & Eco RI & $E c o$ RV & HindIII & $X b a I$ & $\begin{array}{l}\text { Enzymes } \\
\text { showing } \\
\text { polymorphism }\end{array}$ \\
\hline $2 \cdot 7$ & $1 \cdot 7$ & - & nd & nd & - & + & - & nd & 1 \\
\hline 2.9 & 0.6 & + & nd & + & + & + & + & nd & 5 \\
\hline $2 \cdot 11$ & $1 \cdot 1+0 \cdot 6$ & nd & nd & nd & nd & + & nd & nd & 1 \\
\hline $2 \cdot 12$ & $1 \cdot 2$ & + & nd & - & + & nd & + & + & 4 \\
\hline $2 \cdot 16$ & 0.85 & + & nd & - & - & - & - & nd & 1 \\
\hline $5 \cdot 6$ & 0.6 & + & nd & nd & + & + & + & nd & 4 \\
\hline $5 \cdot 8$ & 0.7 & + & + & nd & nd & nd & + & + & 4 \\
\hline $6 \cdot 3$ & 0.75 & + & + & + & + & nd & + & + & 6 \\
\hline 6.9 & 0.8 & + & + & + & + & nd & + & + & 6 \\
\hline $7 \cdot 4$ & 0.67 & - & - & - & - & nd & - & + & 1 \\
\hline $7 \cdot 7$ & $1 \cdot 3$ & - & + & - & - & nd & - & - & 1 \\
\hline $7 \cdot 8$ & 0.75 & + & + & - & + & + & - & + & 5 \\
\hline $7 \cdot 14$ & 0.9 & + & + & - & + & nd & + & + & 5 \\
\hline $7 \cdot 17$ & $1 \cdot 25$ & + & nd & + & - & + & - & nd & 3 \\
\hline $7 \cdot 19$ & 0.76 & + & + & - & - & + & - & nd & 3 \\
\hline $7 \cdot 28$ & 0.75 & + & + & nd & - & + & - & - & 3 \\
\hline $8 \cdot 3$ & 0.4 & + & + & + & - & + & + & nd & 5 \\
\hline $8 \cdot 4$ & 0.6 & + & + & + & + & + & + & nd & 6 \\
\hline 8.9 & $0 \cdot 5$ & + & + & + & - & + & + & nd & 5 \\
\hline $8 \cdot 13$ & $1 \cdot 3$ & + & + & - & + & + & + & - & 5 \\
\hline $8 \cdot 38$ & $1 \cdot 0$ & + & nd & + & - & + & - & nd & 3 \\
\hline $8 \cdot 42$ & $0.63+0.2$ & + & + & nd & - & nd & - & + & 3 \\
\hline $8 \cdot 43$ & 0.85 & + & + & - & - & nd & - & + & 3 \\
\hline $8 \cdot 44$ & 0.9 & - & nd & + & - & - & - & nd & 1 \\
\hline pBG 35 & & - & + & - & + & nd & - & - & 2 \\
\hline $\mathrm{pRC} 221$ & & + & nd & + & + & nd & + & nd & 4 \\
\hline $\mathrm{pAD} 4.4$ & & + & + & + & - & + & + & nd & 5 \\
\hline $\mathrm{pCW} \times 27$ & & + & + & + & + & + & + & + & 7 \\
\hline
\end{tabular}

nd, Not determined; +, Polymorphic; -, Not polymorphic.

Table 6b Polymorphism shown between Optica and 172

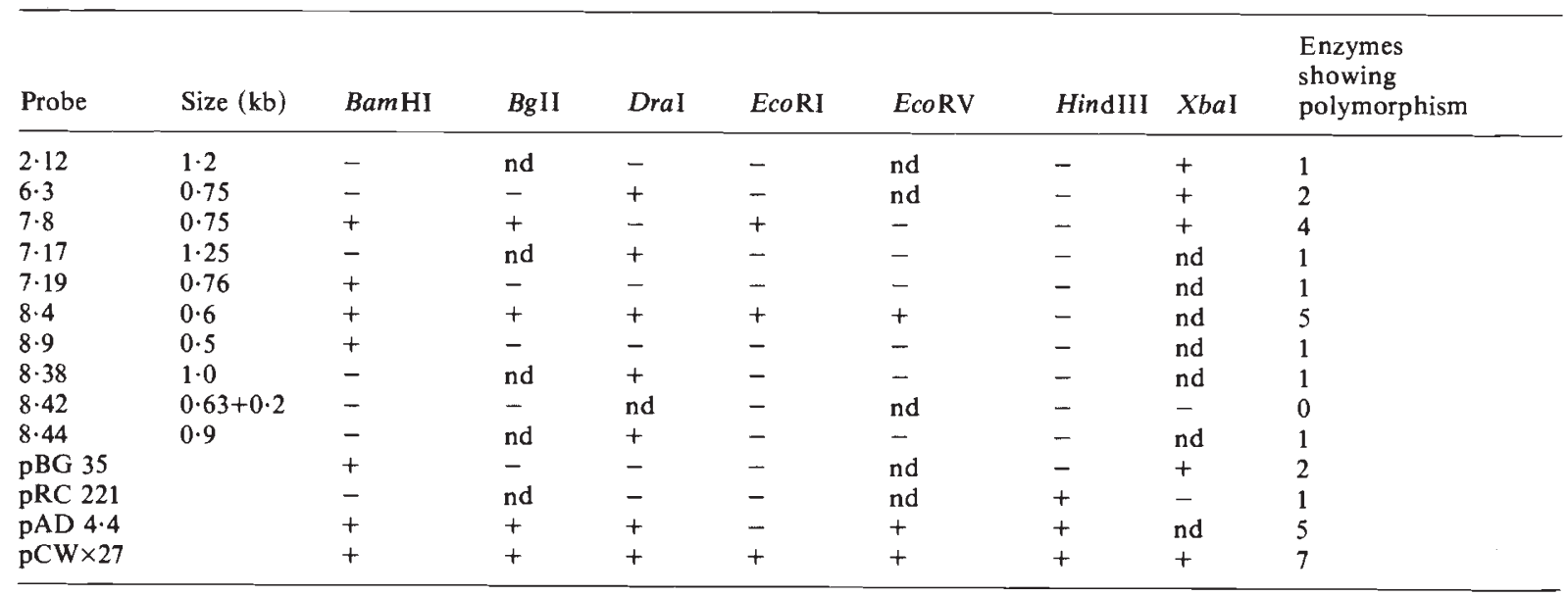


pAD 44 and $\mathrm{pCW} \times 27$ detected polymorphism with a wide range of restriction enzymes.

In order to improve the chances of detecting RFLPs eight 4 bp cutting enzymes were also used. The use of restriction enzymes specific for four nucleotide target sites should increase the probability of detecting polymorphism since the frequency of restriction sites in a given segment of DNA is increased (Kreitman and Aquade, 1986). A sample of 15 probes largely consisting of those not polymorphic for the $6 \mathrm{bp}$ cutters was used in conjunction with the 4 bp cutters. An example of the polymorphism detected is given in fig. 4 for the probe $8 \cdot 3$. Although the resolution of the fragments is increased the frequency of polymorphism detected was not much greater than that detected with $6 \mathrm{bp}$ cutting enzymes, with only one additional polymorphic probe detected using this approach. In contrast to the preliminary survey which was performed with only 4 restriction enzymes, examination of the polymorphisms detected between $\mathrm{A} \times \mathrm{B} \times \mathrm{C}$ and 172 with a wide range of probe $\times$ enzyme combinations indicates that only 4 of the 28 probes detect polymorphism with a single restriction enzyme. The lack of enzyme specificity associated with the detection of polymorphism suggests that alterations in the length of the fragments generated may be due to rearrangements of DNA by insertion or deletion rather than simple point mutations. This is similar to the situation found in soybean (Apuya et al., 1988) and rice (McCouch et al., 1989) where a significant proportion of the RFLPs are due to genomic rearrangements.

The partially allogamous breeding system of Vicia faba is also of relevance and the degree of
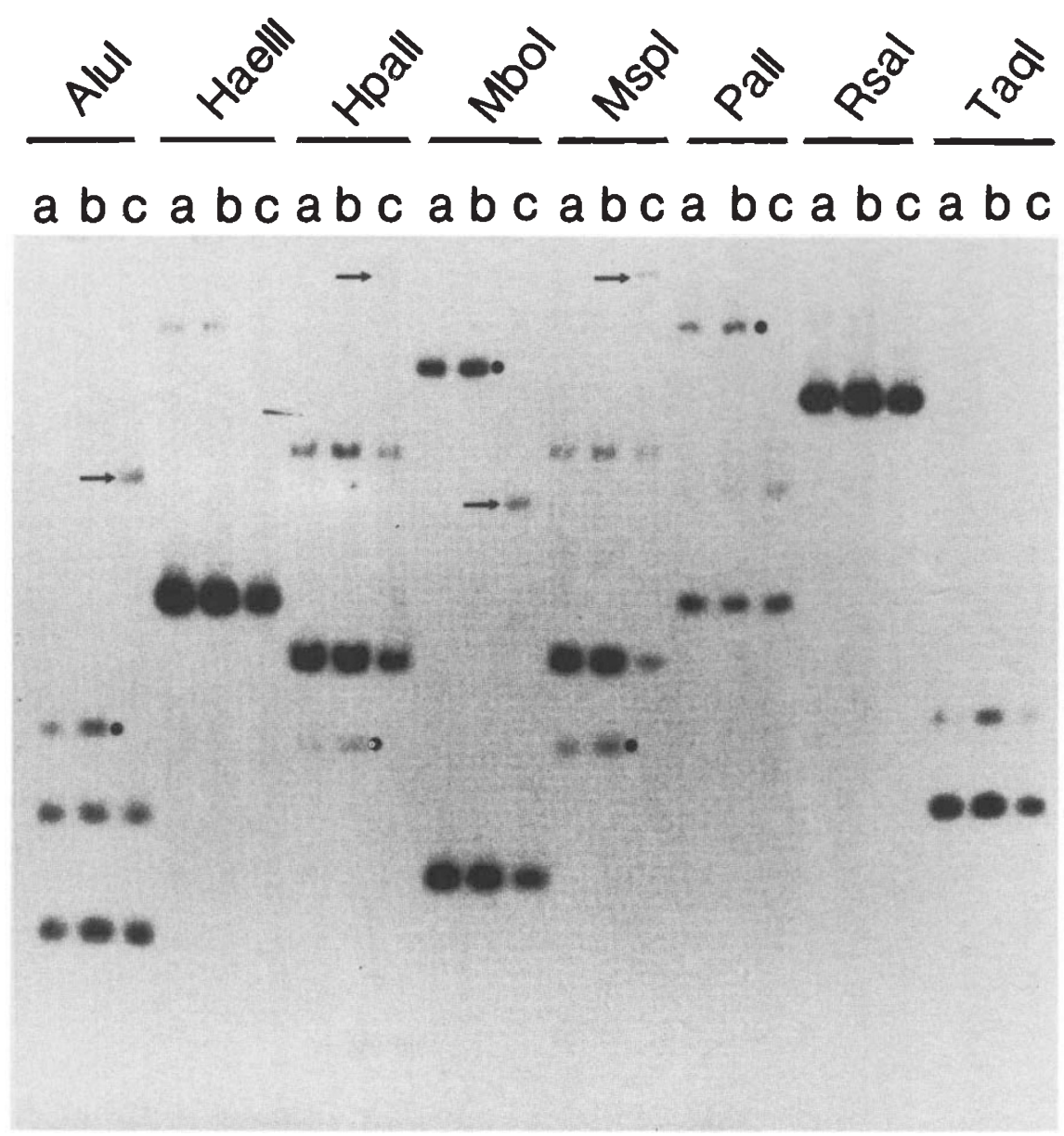

Figure 4 RFLP pattern of Optica, 172 and $A \times B \times C$ probed with cDNA probe $8 \cdot 3$ and restricted with eight four-base-pair recognising enzymes. Dots and arrows indicate the polymorphic bands. 
heterogeneity was assessed on ten individual plants from five of the cultivars used in our initial survey (Optica, A $\times \mathrm{B} \times \mathrm{C}, 172, \mathrm{H} 51 / 3$, Fritel). Two probes in eight probe/enzyme combinations were tested and no within cultivar variability was detected for Optica, $\mathrm{H} 51 / 3$ and 172 . Between plant variability was detected for Fritel, and $\mathrm{A} \times \mathrm{B} \times \mathrm{C}$. The within cultivar variability detected for Fritel is illustrated in fig. 5. A total of six probes in 22 probe/enzyme combinations were examined and the information is given in table 7. All the probes examined were polymorphic with at least one restriction enzyme. For the ten individual plants of Fritel, nine unique
RFLP patterns were found. For $\mathrm{A} \times \mathrm{B} \times \mathrm{C}$ three probes were screened in 10 probe/enzyme combinations (table 8 ). Polymorphism was detected in two plants ( 3 and 5 ) with probe 8.38 in combination with EcoRI and Bam HI.

It is important to note that the polymorphism detected within the Vicia faba cultivars is different from that observed between cultivars and accessions. The polymorphism within cultivars was in minor bands as opposed to the polymorphism in the major hybridising fragments detected between cultivars. Thus the creation of a linkage map based on the RFLP markers identified here
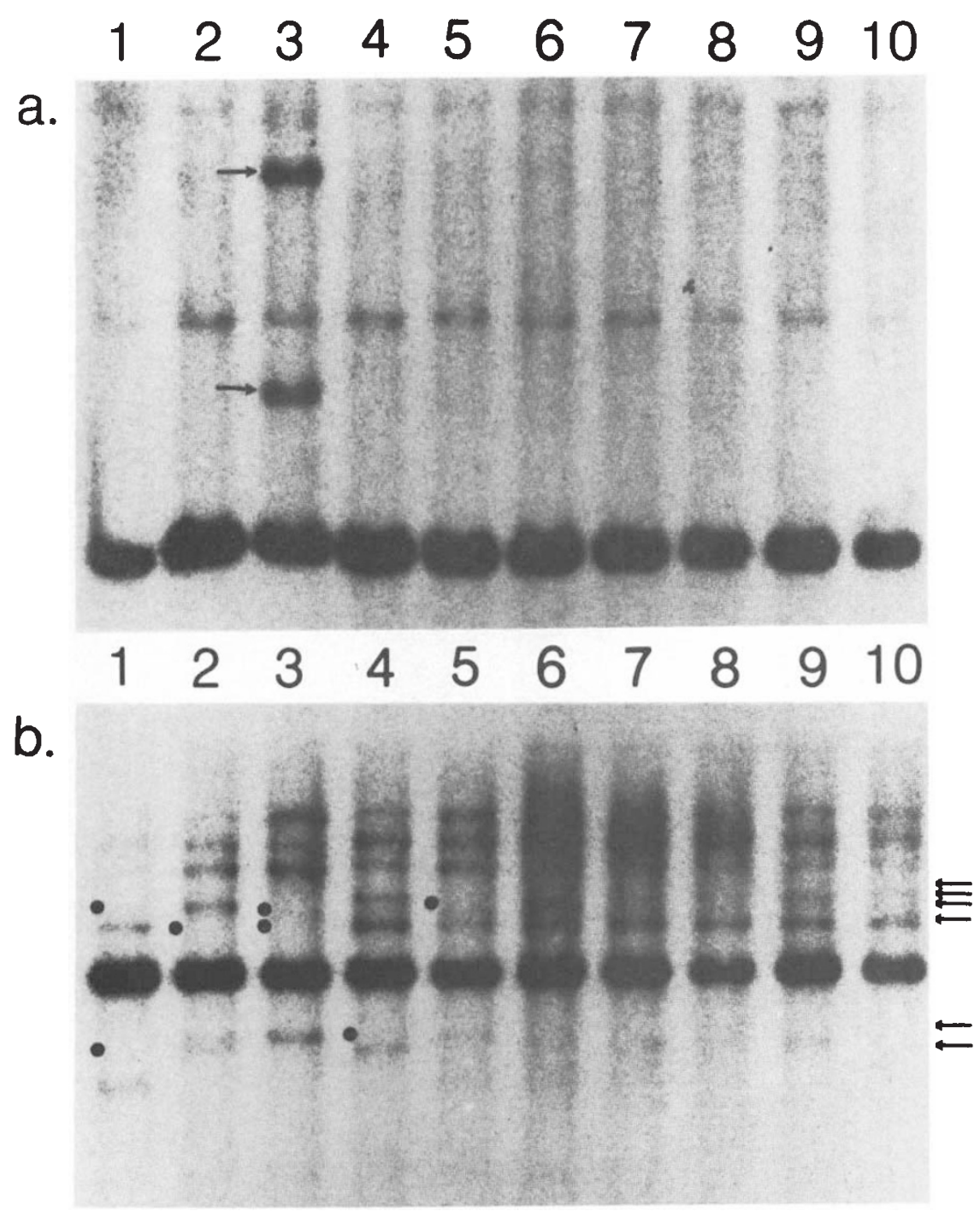

Figure 5 Variation within ten individual Fritel plants probed with cDNA probe 8.4 and restricted with Bam HI (a): (b), EcoRI polymorphism is only detected on minor bands. Arrows and dots indicate polymorphic minor bands. 
Table 7 Polymorphism within Vicia faba $c v$. Fritel

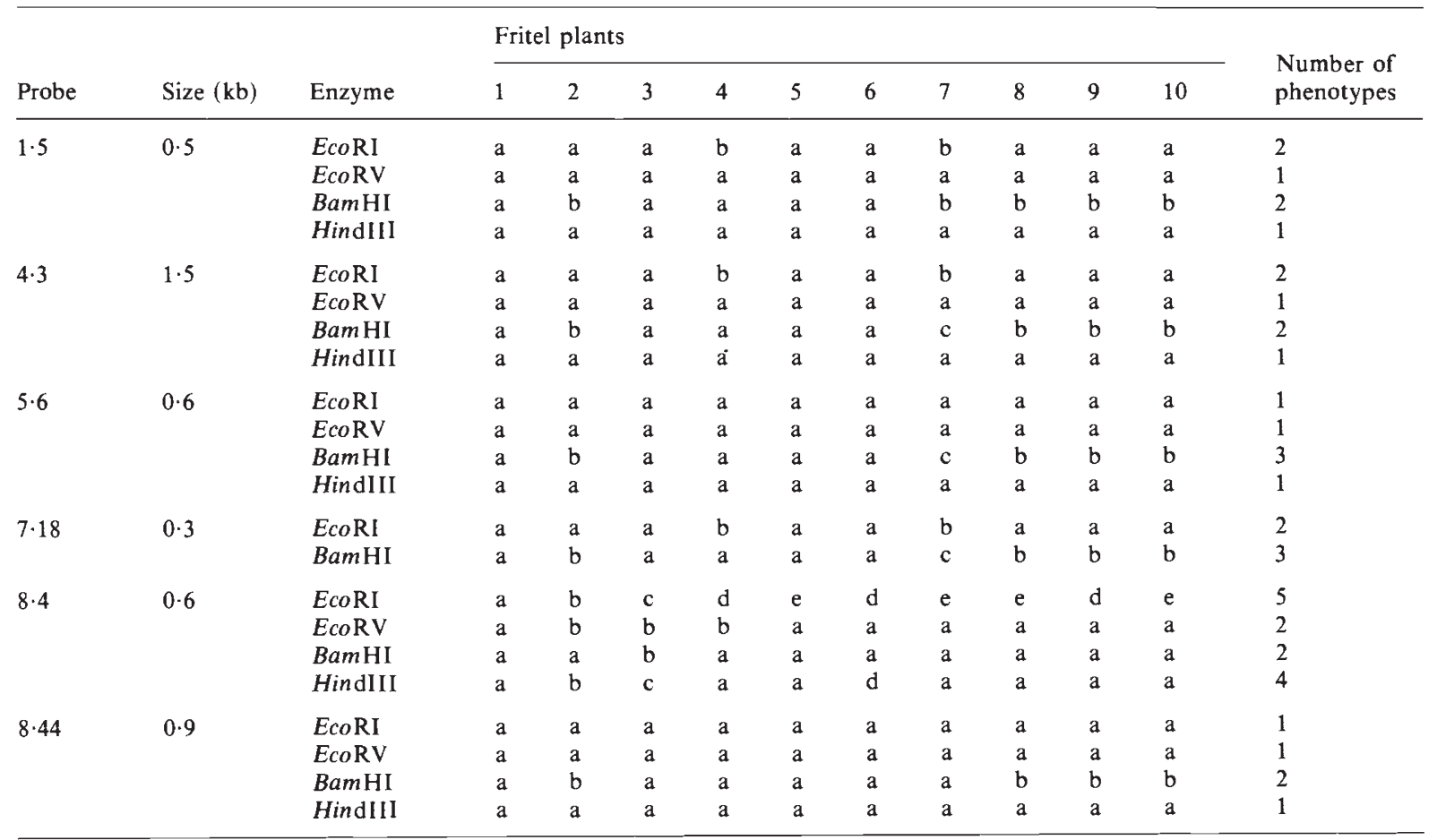

$\mathrm{a}, \mathrm{b}, \mathrm{c}, \mathrm{d}, \mathrm{e}$, different banding patterns.

should not be impeded by the heterogenetiy within a given Vicia accession.

\section{DISCUSSION}

The present manuscript represents the first report to our knowledge of the examination of RFLPs in Vicia. The objectives were to assess the level of polymorphism detectable at the nucleic acid level and identify suitable parents for use in the creation of a linkage map. The choice of parents for genetic mapping studies is of crucial importance. For example, in tomato an interspecific cross had to be analysed to ensure sufficient polymorphism (Tanksley et al., 1989). Interspecific crosses involving $V$. faba cannot be produced and the selection of the most diverse parents for subsequent crossing

Table 8 Polymorphism within Vicia faba $c v . \mathrm{A} \times \mathrm{B} \times \mathrm{C}$

\begin{tabular}{|c|c|c|c|c|c|c|c|c|c|c|c|c|c|}
\hline \multirow[b]{2}{*}{ Probe } & \multirow[b]{2}{*}{ Size $(\mathbf{k b})$} & \multirow[b]{2}{*}{ Enzyme } & \multicolumn{10}{|c|}{$\mathrm{A} \times \mathrm{B} \times \mathrm{C}$ plants } & \multirow{2}{*}{$\begin{array}{l}\text { Number of } \\
\text { phenotypes }\end{array}$} \\
\hline & & & 1 & 2 & 3 & 4 & 5 & 6 & 7 & 8 & 9 & 10 & \\
\hline \multirow[t]{2}{*}{$5 \cdot 6$} & \multirow[t]{2}{*}{0.6} & EcoRI & $\mathrm{a}$ & a & a & a & $\mathrm{a}$ & $\mathrm{a}$ & $\mathrm{a}$ & a & $\mathrm{a}$ & - & 1 \\
\hline & & HindIII & $\mathrm{a}$ & $\mathrm{a}$ & $\mathrm{a}$ & a & a & $\mathrm{a}$ & $\mathrm{a}$ & $\mathrm{a}$ & $\mathrm{a}$ & - & 1 \\
\hline \multirow[t]{4}{*}{$8 \cdot 38$} & \multirow[t]{4}{*}{$1 \cdot 0$} & EcoRI & $\mathrm{a}$ & a & $\mathrm{a}$ & $\mathrm{a}$ & $\mathrm{b}$ & $\mathrm{a}$ & $\mathrm{a}$ & $\mathrm{a}$ & $\mathrm{a}$ & - & 2 \\
\hline & & EcoRV & a & a & $\mathrm{a}$ & $\mathrm{a}$ & $\mathrm{a}$ & $\mathrm{a}$ & $\mathrm{a}$ & $\mathrm{a}$ & $\mathrm{a}$ & - & 1 \\
\hline & & Bam HI & $\mathrm{a}$ & $\mathrm{a}$ & $\mathrm{b}$ & a & $\mathrm{b}$ & $\mathrm{a}$ & $\mathrm{a}$ & $\mathrm{a}$ & $\mathrm{a}$ & - & 2 \\
\hline & & HindlII & $\mathrm{a}$ & $\mathrm{a}$ & $\mathrm{a}$ & $\mathrm{a}$ & $\mathrm{a}$ & $\mathrm{a}$ & $\mathrm{a}$ & $\mathrm{a}$ & $\mathrm{a}$ & - & 1 \\
\hline \multirow[t]{4}{*}{ pAD4.4 } & \multirow[t]{4}{*}{$1 \cdot 1$} & EcoRI & $\mathrm{a}$ & $\mathrm{a}$ & $\mathrm{a}$ & $a$ & $\mathrm{a}$ & $\mathrm{a}$ & $\mathrm{a}$ & $\mathrm{a}$ & $\mathrm{a}$ & - & 1 \\
\hline & & EcoRV & $\mathrm{a}$ & $\mathrm{a}$ & $\mathrm{a}$ & $\mathrm{a}$ & $\mathrm{b}$ & $\mathrm{a}$ & $\mathrm{a}$ & $\mathrm{a}$ & $\mathrm{a}$ & - & 2 \\
\hline & & Bam HI & $\mathrm{a}$ & $\mathrm{a}$ & $\mathrm{a}$ & $\mathrm{a}$ & $\mathrm{a}$ & $\mathrm{a}$ & $\mathrm{a}$ & $\mathrm{a}$ & $\mathrm{a}$ & - & 1 \\
\hline & & HindIII & $\mathrm{a}$ & $\mathrm{a}$ & $\mathrm{a}$ & $\mathrm{a}$ & $\mathrm{a}$ & $\mathrm{a}$ & a & $\mathrm{a}$ & $\mathrm{a}$ & - & 1 \\
\hline
\end{tabular}

$a, b$, different banding patterns. 
is a prerequisite for the creation of a detailed linkage map based on molecular markers. The present study identified the genotype $\mathrm{A} \times \mathrm{B} \times \mathrm{C}$ as a suitable parent due to the relatively large numbers of probes detecting polymorphism with this genotype. It may be relevant to consider the breeding history of $\mathrm{A} \times \mathrm{B} \times \mathrm{C}$. This three way hybrid was created with the objective of maximising the level of heterosis. For this purpose diverse $V$. faba var. equina and var. major accessions from the U.K., Germany and The Netherlands were hybridised with the aid of cytoplasmic male sterility (Duc, personal communication). To our knowledge mutagenesis was not used in the creation of the male sterile stocks but mutagenesis may have a role to play in inducing a higher level of RFLPs (Maluszynski, 1989). It is generally difficult to determine the types of mutation causing the polymorphism detected in RFLP analysis (Landry et al., 1987). However, the polymorphisms associated with $\mathrm{A} \times \mathrm{B} \times \mathrm{C}$ did not appear to be specific to certain restriction enzymes which would suggest that genomic rearrangements may be responsible for the differentiation of $\mathrm{A} \times \mathrm{B} \times \mathrm{C}$ from the other Vicia accessions.

The nature of the polymorphisms identified in Vicia has parallels with that reported for soybean (Keim et al., 1989). In a survey of 58 soybean genotypes the majority of RFLP loci had only two alleles per locus and for some loci one allele was very rare. This is similar to our findings in Vicia where the majority of the polymorphisms are characterised by the presence of 2-3 hybridising bands. Isozyme studies in Vicia (Mancini et al., 1989) have also indicated that multiple alleles are relatively rare. Glutamate oxaloacetate transaminase (GOT) isozymes examined by Mancini et al. at two loci, Got-3 and Got-2, were shown to be under the control of two and three alleles respectively. Superoxide dismutase (SOD) loci were also shown to be under the control of two alleles per locus.

The availability of molecular markers will allow the phylogenetic affinity between different Vicia accessions and species to be examined. The evolution and taxonomy of Vicia species has previously been studied by examining nuclear DNA content (Raina and Rees, 1983; Raina and Narayan, 1984; Brace, 1985; Youssef and Heseman, 1985), the chloroplast (Ko et al., 1987; Ko and Straus, 1986) and the mitochondrial genome (Negruk, 1986). Detailed studies of the nuclear genome have been largely restricted to highly repeated (Kato et al., 1984; Lamppa et al., 1984; Yakura et al., 1984; Rogers and Benedict, 1987) or highly expressed
(Wobus et al., 1984) DNA sequences. The use of low copy cDNA clones identified in the present study will provide another approach to examining DNA diversity in Vicia.

The availability of a linkage map based on molecular markers offers new opportunities for applications in genetics and breeding (Tanksley et al., 1989). In particular the potential of establishing linkage between a diagnostic marker and important agronomic traits is feasible. Future research will focus on the segregation of alleles at RFLP loci in segregating progeny of an $\mathrm{A} \times \mathrm{B} \times \mathrm{C} \times 172$ cross. Currently we have identified a number of polymorphic clones and these will be used for the creation of a linkage map. Primary trisomics can be produced in Vicia faba (Cabrera and Martin, 1989) and these can be used to assign probes rapidly to specific chromosomes via dosage effects as described by Young et al. (1987). In this way we aim to generate a linkage map with genetic markers distributed across the Vicia faba genome. We anticipate that this map will provide a powerful tool for monitoring recombination between specific loci and enable the potential variation available in Vicia faba to be manipulated with greater precision.

Acknowledgements M. van de Ven wishes to thank the AFRC for a post-graduate studentship. We thank the various research workers listed in table 2 for the supply of cDNA clones of known function.

\section{REFERENCES}

APUYA, N. R., FRAIER, B. L., KEIM, P., JILL-ROTH, E. AND LARK, K. G. 1988. Restriction fragment length polymorphism as genetic markers in soybean Glycine max (L.) Merrill. Theor. appl. Genet., 75, 889-901.

BASSIRI, A. AND ROUMANI, I. 1977. Identification of broad bean cultivars based on isozyme patterns. Euphytica 26, 279-286.

BERNATZKY, R. AND TANKSLEY, S. D. 1986. Towards a saturated linkage map in tomatoes based on isozyme and random cDNA sequences. Genetics, 112, 887-898.

Bonierbale, M. W., PLAisted, R. L. AND TANKSLEY, S. D. 1988. RFLP maps based on a common set of clones reveal modes of chromosomal evolution in tomato and potato. Genetics, 120, 1095-1103.

BRACE, J. 1985. The DNA of crop plants and their wild relatives. In Barigozzi, C. (ed.) The Origin and Domestication of Cultivated Plants. pp. 121-128. Elsevier, Amsterdam.

BURR, B., THOMPSON, K. H., ALBERTSON, M. C. AND STUBER, C. W. 1988. Gene mapping with recombinant inbreds in maize. Genetics, 118, 519-526.

CABRERA, A. AND MARTIN, A. 1989. Analysis of genetic linkage in faba bean (Vicia faba L.). FABIS Newslett., 24, 4-7.

FEINBERG, A. P. AND VOGELSTEIN, B. 1984. A technique for radiolabelling DNA restriction endonuclease fragments to high specific activity. Analyt. Biochem., 137, 266-267. 
GATES, P. AND BOULTER, D. 1979. The use of seed isozymes as an aid to the breeding of field beans (Vicia faba L). New Phytol., 83, 783-791.

GATES, P. AND BOULTER, D. 1980. The use of pollen isoenzymes as an aid to the breeding of field beans (Vicia faba L.). New Phytol., 83, 783-791.

GEBHARDT, C., RITTER, E., DEBENER, T., SCHACHTSCHABEL, U., WALKMEIER, B., UHRIG, H. AND SALAMINI, F. 1989. RFLP-analysis and linkage mapping in Solanum tuberosum. Theor. appl. Genet., 78, 65-75.

Goldsbrough, P. B., ELliS, T. H. M. AND CULLIS, C. A. 1981. Organisation of the 5S RNA genes in flax. Nucleic Acid Res., 9, 5895-5904.

GOLDSBROUGH, P. B. AND CULLIS, C. A. 1981. Characterisation of the genes for ribosomal RNA in flax. Nucleic Acid Res., 9, 1301-1309.

HEBBLETHWAITE, P. D., DAWKINS, T. C. K., HEATH, M. C. AND LOCKWoOD, G. 1984. Vicia faba, Agronomy, Physiology and Breeding. World Crops: Production, Utilization, Description, Vol. 10. Nijhoff, M. (ed.), Dr W. Junk, Publishers.

HELENTJARIS, T., SLOCUM, M., WRIGHT, S., SCHAEFER, A. AND NIENHUIS, J. 1986. Construction of genetic linkage maps in maize and tomato using restriction fragment length polymorphism. Theor. appl. Genet., 72, 761769.

KASER, H. R. AND STEINER, A. M. 1983. Subspecific classification of Vicia faba L by protein and isozyme patterns. FABIS Newslett., 7, 19-20.

KATO, A., YAKURA, K. AND TANIFUJI, S. 1984. Sequence analysis of Vicia faba repeated DNA, the FOKI repeat element. Nucleic Acid Res., 12, 6415-6426.

KEIM, P., SHOEMAKER, R. C. AND PALMER, R. G. 1989. Restriction fragment length polymorphism diversity in soybean. Theor. appl. Genet., 77, 786-792.

KO, K. AND STRAUSS, N. A. 1986. The chloroplast genome of Vicia faba. Third Conspectus of Genetic Variation Within Vicia faba, FABIS (Faba Bean Information Service), ICARDA, pp. 8-18.

KO, K., ORFANIDES, A. G. AND STRAuSS, N. A. 1987. A model for the evolution of the Vicia faba chloroplast genome. Theor. appl. Ge: et., 74, 125-139.

KREITMAN, M. AND AQUADE, M. 1986. Genetic uniformity in two populations of Drosophila melanogaster as revealed by four-cutter filter hybridisation. Proc. Natl Acad. Sci. USA, 83, 3562-3566.

LAMPPA, G. K., HONDA, S. AND BENDICH, A. J. 1984. The relationship between ribosomal repeat length and genome size in Vicia. Chromosoma, 89, 1-7.

LANDRY, B. S., KESSELI, R. V., FARRARA, B. AND MICHELMORE, R. W. 1987. A genetic map of lettuce (Lactuca sativa L) with restriction fragment length polymorphism, isozyme, desease resistance and morphological markers. Genetics, 116, 331-337.

LYCETT, G. W., DROY, R. D., SHIRSAT, A. D. AND BOULKER, D. 1984. The complete nucleotide sequence of a legumin gene from peak (Pisum sativum L.). Nucleic Acid Res., 12, 4493-4506.

LOGEMANN, J., SCHELL, J. AND WILLMITZER, L. 1987. Improved method for the isolation of RNA from plant tissues. Analyt. Biochem., 163, 16-20.

MANCINI, R., DE PACE, C., MUGNOZZA, G. T. S., DELRE, V. AND VITTORI, D. 1989. Isozyme gene markers in Vicia faba L. Theor, appl. Genet, 77, 657-667.

MANIATIS, T., FRITSH, E. F. AND SAMBROOK, J. 1982. Molecular Cloning, a Laboratory Manual. Cold Spring Harbor Laboratory, 545pp.
MCCOUCH, S. R., KOCHERT, G., YU, Z. H., WANG, Z. Y., KHUSH, G. S., COFFMAN, W. R. AND TANKSLEY, S. D. 1989. Molecular mapping of rice chromosomes. Theor. appl. Genet., 76, 815-829.

MALUSZYNSKI, M. 1990. Induced mutations-An Integrating Tool in Genetics and Plant Breeding. Stadler Genetics Symposium (in press).

Michelmore, R. W. AND hulbert, S. H. 1987. Molecular markers for genetic analysis of phytopathogenetic fungi. A. Rev. Phytopathol., 25, 383-404.

NEGRUK, V. 1986. The Vicia faba mitochondrial genome. Biol. Zentralbl., 105, 95.

NEI, M. AND LI, w. H. 1979. Mathematical model for studying genetic variation in terms of restriction endonucleases. Proc. Natl Acad. Sci. USA, 76, 5267-5273.

NIENHUIS, J., HELENTJARIS, M., SLOCUM, M., RUGGERO, B. AND SCHAEFER, A. 1987. Restriction fragment length polymorphism analysis of loci associated with insect resistance in tomato. Crop Sci, , 27, 797-803.

PATERSON, A. H., LANDER, E. S., HEWITT, J. D., PETERSON, S., LINCOLN, S. E. AND TANKSLEY, S. D. 1988. Resolution of quantitative traits into Mendelian factors by using a complete linkage map of restriction fragment length polymorphisms. Nature, 335, 721-726.

PEAT, W. E. AND ADHAM, J. Y. 1984. The use of isozymes genes as markers in the population genetics of Vicia faba L. In: Chapman, G. P. and Tarawali, S. A. (eds). Systems for Cytogenetic Analysis in Vicia faba L.Adv. agric. Biotechnol, $11,109-117$.

RAINA, S. N. AND REES, H. 1983. DNA variation between and within chromosome complements of Vicia species. Heredity, 51, 335-346.

RAINA, S. N. AND NARAYAN, R. K. J. 1984. Changes in DNA composition in the evolution of Vicia species. Theor. appl. Genet., 68, 187-192.

RAMSAY, G. AND PICKERSGILL, B. 1986. Interspecific hybridisation between Vicia faba and other species of Vicia: Approaches to delaying embryo abortion. Biol. Zentralbl., 105, 171-179.

REED, K. C. AND MANN, D. A. 1985. Rapid transfer of DNA from agarose gels to nylon membranes. Nucleic Acid Res., 13, 7207-7221.

RHODE, W., BARZEN, E., MAROCCO, A., SCHWARZ-SOMMER, Z., SAEDLER, H. AND SALAMINI, F 1987. Isolation of genes that could serve as traps for transposable elements in Hordeum vulgare. Barley Genet, 533-541.

ROGERS, S. O. AND BENDICH, A. J. 1987. Heritability and variability in ribosomal RNA genes of Vicia faba. Genetics, $117,285-295$.

SAGHAI-MAROOF, M. A., SOLIMAN, K. M., JORGENSEN, R. A AND ALLARD, R. W. 1984. Ribosomal DNA spacer-length polymorphism in barley: Mendelian inheritance chromosomal location and population dynamics. Proc. Natl Acad. Sci. USA, 81, 8014-8018.

SILHAVY, T. J., BERMANN, M. L. AND ENQUIST, L. W. 1984 Experiments with Gene Fusions. Cold Spring Harbor Laboratory, 304pp.

TAIT, R. C., FROMAN, B. E., LAUDENCIA-CHINGCUANCO, D. L. AND GOTTlieB, L. D. 1988. Plant phosphoglucose isomerase genes lacks introns and are expressed in Escherichia coli. Pl. molec. Biol, 11, 381-388.

TANKSLEY, S. D. AND ORTON, T. J. 1983. Isozymes in Plant Genetics and Breeding. Elsevier, Amsterdam.

TANKSLEY, S. D., YOUNG, N. D., PATERSON, A. H. AND BONIERBALE, M. W. 1989. RFLP mapping in plant breeding: New tools for an old science. Biotechnology, 7, 257-264. 
WARD, S. AND CHAPMAN, G. P. 1986. Third Conspectus of Genetic Variation Within Vicia faba. Int. Center for Agric Res in Dry Areas (ICARDA), Aleppo, Syria.

WOBUS, U., BAUMLEIN, H., BASSUNER, R., HEIM, U., JUNG, R., MUNTZ, K., PANITZ, R., SAALBACH, G. AND WESCHKE, W. 1984. Molecular characterisation of Vicia faba storage protein specific DNA. Kulturpflanze, 32, 117-126.

YAKURA, K., KOTO, A. AND TANIFUJI, S. 1984. Length heterogenetiy of the large spacer of Vicia faba rDNA is due to the differing number of a $325 \mathrm{bp}$ repetitive sequence elements. Molec. gen. Genet., 193, 400-405.
YAMAMOTO, K. 1986. A note on interspecific hybridisation between Vicia narbonensis and its related species. Biol. Zentralbl., 105, 181-197.

YOUNG, N. D., MILLER, J. C. AND TANKSLEY, S. D. 1987. Rapid chromosomal assignment of multiple genomic clones in tomato using primary trisomics. Nucleic Acid Res., 15, 9339-9348.

YOUSSEF, S. S. AND HESEMANN, C. U. 1985. Nuclear DNA contents of some species of Vicia L. and some Egyptian varieties of Vicia faba L. Egypt. J. Genet. Cytol., 14, 111121. 